\title{
PENGGUNAAN VIDEO DEMONSTRASI LARUTAN BUFFER MENGGUNAKAN MODEL TGT DAN MAKE A MATCH TERHADAP HASIL BELAJAR SISWA
}

\section{USING THE BUFFER SOLUTION DEMONSTRATION VIDEO USING THE TGT MODEL AND MAKE A MATCH ON STUDENT LEARNING RESULTS}

\author{
Samsinur* \\ Universitas Islam Sumatera Utara, Department of Chemistry Education, Medan 20217, \\ North Sumatera, Indonesia \\ *Corresponding author: samsinur@gmail.com
}

\begin{abstract}
ABSTRAK
Penelitian ini bertujuan untuk mengetahui perbedaan hasil belajar siswa menggunakan model $T G T$ (Teams Games Tournament) dengan siswa yang diajar dengan model Make A Match menggunakan video demonstrasi larutan buffer. Hasil belajar siswa yang dibelajarkan menggunakan $T G T$ pada materi larutan penyangga dikelas XI IPA SMAN 1 Tanjung Tiram memiliki nilai rata-rata pre-test adalah 62,89 dan nilai rata-rata untuk post-test adalah 81,184 , sedangkan Hasil belajar siswa yang dibelajarkan menggunakan Make A Match pada materi larutan penyangga dikelas XI IPA SMAN 1 Tanjung Tiram memiliki nilai rata-rata pre-test adalah 44,3 dan nilai rata-rata untuk post-test adalah 73,421 . Untuk uji normalitas data pada kelas eksperimen I menggunakan model TGT dan pada kelas eksperimen II menggunakan model Make A Match dan post-test kedua sampel berdistribusi normal. Pada uji Homogenitas kedua kelas sampel homogen. Berdasarkan hasil perhitungan statistik yang menggunakan hasil hipotesis dalam penelitian ini yaitu dan Ha diterima dengan nilai $t_{\text {hitung }}>t_{\text {tabel }}$ yaitu 7,91 >1,99 Maka dari hasil analisa terhadap rumusan hipotesis menunjukkan bahwa ada perbedaan hasil belajar siswa yang dibelajarkan menggunakan video demonstrasi pada materi larutan buffer dikelas XI IPA SMAN 1 Tanjung Tiram.
\end{abstract}

Kata kunci: Hasil belajar; Teams games tournament; Make a match.

\begin{abstract}
This study aims to determine the differences in student learning outcomes using the TGT (Teams Games Tournament) model with students being taught the Make A Match model using a buffer solution demonstration video. The learning outcomes of students who were taught using TGT on the buffer solution material in class XI IPA SMAN 1 Tanjung Tiram had an average pre-test score of 62.89 and the average score for the post-test was 81,184, while student learning outcomes who were taught using Make A Match on the buffer solution material in class XI IPA SMAN 1 Tanjung Tiram has an average pre-test value of 44.3 and the average value for the post-test is 73.421. To test the normality of the data in the experimental class I used the TGT model and in the experimental class II used the Make A Match model and the post-test both samples were normally distributed. In the homogeneity test, the two sample classes are homogeneous. Based on the results of statistical calculations using the results of the hypothesis in this study, namely and Ha accepted with a value of tcount> ttable, namely 7.91> 1.99. So from the results of the analysis of the formulation of the hypothesis, it shows that there are differences in student learning outcomes who are taught using video demonstrations on the solution material. buffer class XI IPA SMAN 1 Tanjung Tiram.
\end{abstract}

Keywords: Learning outcomes; Teams games tournament; Make a match. 


\section{PENDAHULUAN}

Pembelajaran yang dilakukan oleh guru kimia cenderung menggunakan model pembelajaran langsung (Direct Insruction). Berdasarkan pengamatan peneliti di SMA Negeri 1 Tanjung Tiram, masih banyak guru khususnya guru kimia menggunakan model pembelajaran langsung (Direct Insruction) sehingga proses pembelajaran cenderung monoton. Hal ini juga didukung oleh Markono (2011:613) "salah satu problema yang sejak dulu muncul dalam proses pembelajaran atau secara lebih spesifik berkenaan dengan metode mengajar, proses pembelajaran didominasi oleh model pembelajaran langsung (konvensional)".

Kartika (2015:1) mengatakan bahwa kondisi yang terjadi ketika pembelajaran langsung diterapkan maka tujuan pembelajaran akan sulit tercapai. Hal ini terjadi karena guru kurang melatih bagaimana cara berpikir siswa secara bertahap melalui model pembelajaran yang tepat untuk memahami materi yang dipelajari. Hal ini telah dikemukakan oleh Muslim (2015:77) dalam penelitiannya, "Guru kurang melatih bagaimana cara berpikir siswa secara bertahap melalui strategi pembelajaran yang tepat untuk memahami fakta dan konsep yang dipelajari, sehingga siswa kurang mengetahui manfaat dari mempelajari materi larutan buffer".

Larutan buffer termasuk materi pelajaran kimia yang dianggap sulit karena larutan buffer (penyangga) ini merupakan salah satu pokok bahasan kimia yang menggunakan suatu reaksi dan perhitungan. Suyono,dkk (2009:56) mengatakan bahwa siswa berasumsi pelajaran kimia tidak menarik dan sulit dipahami terutama dalam hal perhitungan dan reaksi kimia karena metode mengajar guru kurang bervariasi dan tidak inovatif.

Peran guru dalam pembelajaran adalah fasilitator, mediator, dan pembimbing. Dalam proses pembelajaran, keberhasilan pembelajaran diukur berdasarkan pada ketercapaian kompetensi yang ditetapkan sejak awal kegiatan pembelajaran. Guru dan siswa harus bekerja sama sedemikian rupa, saling mendukung sehingga memungkinkan tercapainya kompetensi yang ditetapkan. Untuk melaksanakan kegiatan belajar mengajar diperlukan langkah-langkah agar tujuan yang ditetapkan dapat dicapai. Unsur yang amat penting dalam suatu proses belajar-mengajar adalah metode mengajar dan media pengajaran yang sesuai dengan materi pelajaran yang diajarkan, kedua aspek ini saling berkaitan.

Kecenderungan sikap guru yang memberikan pelajaran kimia dengan ceramah, mengajak siswa untuk membaca bahan ajar dan menghafalkannya cenderung membuat siswa merasa bosan, jengkel dan tidak adanya kemauan dalam benak siswa untuk mendalaminya. Guru dapat membuat siswa merasa tertarik dan termotivasi dengan berbagai cara,salah satunya adalah dengan menggunakan media dan metode pembelajaran yang berbeda dan menarik karena pemakaian media pengajaran dalam proses belajar mengajar dapat membangkitkan keinginan dan minat yang baru, membangkitkan motivasi dan rangsangan kegiatan belajar, bahkan membawa pengaruh-pengaruh psikolog terhadap siswa.

Menurut hasil observasi dan wawancara dengan guru mata pelajaran, SMA Negeri 1 Tanjung Tiram, hasil yang diperoleh melalui wawancara dengan guru mata pelajaran kimia diperoleh data hasil belajar kimia siswa yang dicapai pada umumnya masih rendah. Fakta ini diperoleh dari data penilaian ujian semester pada siswa kelas XI dengan nilai antara 60-80 dan nilai rata-rata kelas 68,sedangkan KKM kami disekolah ini adalah 70, meskipun KKM sudah tercapai, namun nilai yang diperoleh siswa sudah ada nilai tambahan dari guru yaitu penilaian guru terhadap tugas pribadi/kelompok, kehadiran siswa, dan disiplin siswa. Rendahnya nilai kimia siswa, disebabkan siswa kurang paham dengan materi yang disampaikan kepadanya. Dari faktor utama penyebab kurangnya hasil belajar siswa dalam belajar kimia maka perlu usaha peningkatan hasil belajar yaitu dengan menambah variasi model pembelajaran, serta media pembelajaran yang menarik atau menyenangkan. Salah satu model pembelajaran kooperatif merupakan tindakan pemecahan yang dilakukan karena dapat meningkatkan kemajuan belajar, sikap siswa yang lebih positif, menambah motivasi dan percaya diri serta menambah rasa senang.

Pembelajaran dengan metode TGT dan Make A Match ini akan lebih menarik jika disajikan dengan media teknologi. Salah satu media yang digunakan ialah video demonstrasi. Menurut Ismayanti (2010) menyatakan multimedia bertujuan untuk menyajikan informasi dalam bentuk yang menyenangkan, menarik mudah dimengerti dan jelas. Salah satunya adalah VCD sebagai media berbasis komputer yang bertujuan untuk menyajkan informasi dalam bentuk yang menyenangkan, menarik, mudah dimengerti dan jelas. Sesuai dengan dengan uraian diatas kegunaan VCD disini sebagai 
media berbasis komputer yang dapat membuat pelajaran lebih menarik, menyenangkan dan mudah dimengerti.

Aktivitas belajar dengan media video yang dilakukan dalam model pembelajaran TGT (Teams Games and Tournament) dan Make A Match memungkinkan siswa dapat belajar lebih rileks dan menyenangkan di samping menumbuhkan tanggungjawab, kerjasama, persaingan sehat, keterlibatan belajar. Seperti karakteristik pembelajaran kooperatif lainnya, tehnik TGT dan Make A Match memunculkan adanya kelompok dan kerjasama dalam belajar, di samping itu terdapat persaingan antara individu dalam kelompok maupun antar kelompok. Dalam teknik TGT dan Make A Match, siswa yang mempunyai kemampuan dan jenis kelamin berbeda dijadikan dalam sebuah tim yang terdiri dari 4-5 siswa. Setelah guru memberi kelompok yang heterogen, siswa melaksanakan aktivitas belajar dengan media komputer. Salah satu teori belajar menegaskan bahwa sesulit apapun materi pelajaran apabila dipelajari dalam suasana yang menyeanangkan pelajaran tersebut akan mudah dipahami. Sebaliknya walaupun materi pelajaran tidak terlampau sulit untuk dipelajari, namun apabila suasana belajar membosankan, tidak menarik, dan siswa belajar dibawah tekanan, maka materi pelajaran menjadi sulit di pahami. Dari sinilah penulis tertarik untuk mengadakan penelitian dengan judul: "Penggunaan Video Demonstrasi Larutan Buffer Menggunakan Model TGT dan Make A Match Terhadap Hasil Belajar Siswa SMAN 1 Tanjung Tiram".

\section{METODE PENELITIAN}

\subsection{Jenis Penelitian}

Jenis penelitian adalah penelitian eksperimen, dimana dalam penelitian ini dilakukan pengamatan serta uji coba langsung ke target yang direncanakan menggunakan kelompok yang dianalisis

\subsection{Waktu dan Tempat Penelitian} semester II

Penelitian ini dilaksanakan di SMAN 1 Tanjung Tiram, waktu penelitian ini dilaksanakan pada

\subsection{Target/Subjek Penelitian}

Target penelitian ini adalah seluruh siswa kelas XI SMAN 1 Tanjung Tiram yang terdiri dari 4 kelas dan jumlah siswa keseluruhan siswa kelas XI adalah sebanyak 152 orang. Subjek penelitian ini adalah kelas XI-1 dan X-4 yang berjumlah 38 dan 38 orang di masing-masing kelas. Kelas X-1 dan X4 merupakan kelas unggulan dari kelas XI lainnya

\subsection{Prosedur}

Adapun prosedur pelaksanaan penelitian ini adalah:

\section{Tahap Persiapan}

a. Menyusun jadwal penelitian disesuaikan dengan jadwal yang ada di sekolah

b. Menyusun rencana pembelajaran dengan menggunakan model pembelajaran kooperatif tipe TGT menggunakan media video demonstrasi dan menyusun rencana pembelajaran dengan menggunakan model pembelajaran kooperatif tipe Make A Match menggunakan media video demonstrasi.

c. Membuat instrument penelitian

d. Memvalidkan instrument penelitian.

2. Tahap Pelaksanaan

a. Memberikan pretest untuk melihat kemampuan awal kelas eksperimen 1 dan kelas eksperimen 2;

b. Mengelompokkan siswa berdasarkan hasil pretest

c. Pelaksanaan pembelajaran dilakukan dengan menerapkan modal TGT menggunakan media video demonstrasi dan model pembelajaran Make A Match menggunakan media video demonstrasi.

d. Memberikan post-test (test akhir).

e. Test akhir diberikan setelah pembelajaran dengan kedua model tersebut terselesaikan. 


\section{Tahap Akhir}

Pada tahap ini data yang didapat dari kedua kelas diolah dan dianalisis dengan uji statistik untuk melihat perbedaan signifikan dari hasil belajar siswa pada kedua kelas eksperimen, kemudian menarik kesimpulan terhadap penelitian.

\subsection{Data, Instrumen, dan Teknik Pengumpulan Data}

Instrument penelitian yang digunakan adalah instrument tes. Tes merupakan alat atau prosedur yang digunakan untuk mengetahui atau mengukur sesuatu dengan cara dan aturan-aturan yang sudah ditentukan. Tes digunakan sebelum dan sesudah perlakuan pada sampel. Instrument penilaian ini adalah evaluasi belajar (pre-test dan post-test) berupa tes tertulis (pilihan berganda), untuk kelas eksperimen 1 dan kelas eksperimen 2 dengan materi yang sama. Jumlah soal yang digunakan sebanyak 20 buah dengan pilihan jawaban sebanyak 5 buah. Sebelum dilakukan penelitian instrument tes yang telah disusun terlebih dahulu diuji cobakan untuk mengetahui validitas, reabilitas, daya beda dan tingkat kesukaran tes.

\subsection{Teknik Analisis Data}

Data yang diperoleh dari hasil penelitian dianalisis dengan langkah-langkah adalah (1) Menentukan rata-rata skor masing-masing kelompok; (2) Uji normalitas data; (3) Uji homogenitas data; (4) Uji hipotesis; dan (5) Uji peningkatan hasil belajar (Gain).

\section{HASIL DAN PEMBAHASAN}

\subsection{Deskripsi Data Penelitian}

Dalam penelitian diperoleh data dari dua bagian yaitu, data sebelum diberikan perlakuan yang diambil melalui pre-test yang disebut dengan data awal dan data hasil setelah diberikan perlakuan yang diambil melalui post-test yang disebut data akhir.

Tabel 1. Data nilai pretes kelas eksperimen I dan eksperimen II

\begin{tabular}{|c|c|c|c|c|c|c|c|}
\hline \multicolumn{2}{|c|}{ Kelas Eksperimen I } & \multicolumn{6}{|c|}{ Kelas Eksperimen II } \\
\hline $\begin{array}{l}\text { Nilai } \\
\text { Pretes }\end{array}$ & Frekuensi & $\begin{array}{c}\text { Rata- } \\
\text { rata }\end{array}$ & $\begin{array}{l}\text { Standar } \\
\text { deviasi }\end{array}$ & $\begin{array}{l}\text { Nilai } \\
\text { Pretes }\end{array}$ & Frekuensi & $\begin{array}{c}\text { Rata- } \\
\text { rata }\end{array}$ & $\begin{array}{r}\text { Standar } \\
\text { deviasi }\end{array}$ \\
\hline 50 & 4 & \multirow{6}{*}{62,89} & \multirow{6}{*}{7,5901} & 50 & 1 & \multirow{6}{*}{44,3} & \multirow{6}{*}{7,458} \\
\hline 55 & 8 & & & 55 & 5 & & \\
\hline 60 & 7 & & & 60 & 9 & & \\
\hline 65 & 10 & & & 65 & 14 & & \\
\hline 70 & 6 & & & 70 & 5 & & \\
\hline 75 & 5 & & & 75 & 4 & & \\
\hline & $\Sigma=38$ & & & & $\Sigma=38$ & & \\
\hline
\end{tabular}

Berdasarkan tabel 1 dapat diketahui pada kelas eksperimen I dan kelas eksperimen II memiliki kemampuan awal yang sama, hal ini diketahui dari nilai rata-rata pretes kedua kelas tersebut, dimana pada kelas eksperimen I dan kelas eksperimen II diperoleh rata-rata nilai yang masih tergolong sangat rendah, sehingga penelitian ini perlu dilanjutkan.

Tabel 2. Data nilai postest kelas eksperimen I dan eksperimen II

\begin{tabular}{|c|c|c|c|c|c|c|c|}
\hline \multicolumn{4}{|c|}{ Kelas Eksperimen I } & \multicolumn{4}{|c|}{ Kelas Eksperimen II } \\
\hline $\begin{array}{l}\text { Nilai } \\
\text { Pretes }\end{array}$ & Frekuensi & $\begin{array}{c}\text { Rata- } \\
\text { rata }\end{array}$ & $\begin{array}{l}\text { Standar } \\
\text { deviasi }\end{array}$ & $\begin{array}{l}\text { Nilai } \\
\text { Pretes }\end{array}$ & Frekuensi & $\begin{array}{c}\text { Rata- } \\
\text { rata }\end{array}$ & $\begin{array}{l}\text { Standar } \\
\text { deviasi }\end{array}$ \\
\hline 70 & 3 & \multirow{4}{*}{81,184} & \multirow{4}{*}{5,506} & 65 & 2 & \multirow{4}{*}{73,421} & \multirow{4}{*}{6,688} \\
\hline 75 & 5 & & & 70 & 3 & & \\
\hline 80 & 15 & & & 75 & 9 & & \\
\hline 85 & 10 & & & 80 & 12 & & \\
\hline
\end{tabular}




\begin{tabular}{cccc}
\hline \multicolumn{1}{c}{5} & & 85 & 10 \\
\cline { 3 - 3 } & & 90 & 2 \\
\cline { 3 - 3 } & & & \\
\hline & & & \\
\hline & & & \\
\hline
\end{tabular}

Berdasarkan Tabel diatas, dapat dilihat adanya perbedaan rata-rata hasil belajar siswa, dimana kelas eksperimen I yang diajarkan menggunakan model pembelajaran Team Games Tournament lebih tinggi daripada rata-rata kelas model pembelajaran Make A Match.

Penelitian ini menggunakan dua eksperimen, kelas eksperimen I dan kelas eksperimen II. Kedua kelas eksperimen menggunakan pre-tes yang sama untuk melihat kemampuan awal siswa Berikut gambar grafik untuk menunjukkan data nilai pre-test pada kelas Eksperimen I dan kelas Eksperimen II.

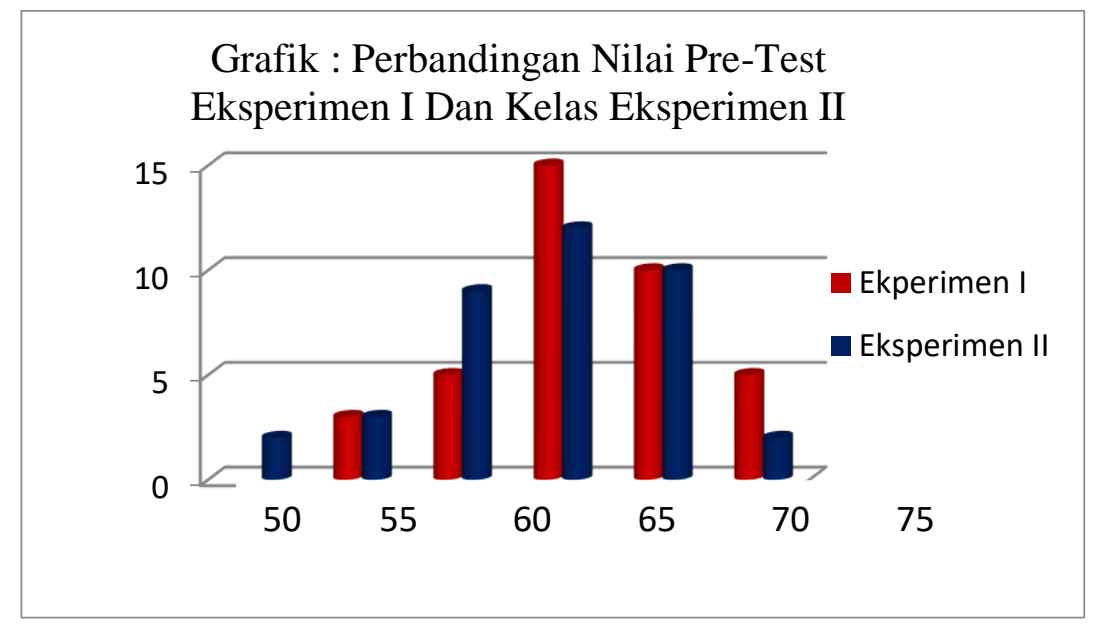

Gambar 1. Perbandingan nilai post-test Eksperimen I dengan Eksperimen Il

Dari hasil pre-test pada kedua kelas eksperimen, terdapat siswa yang mencapai nilai KKM, dan nilai KKM adalah 70 terdiri dari 15 siswa untuk kelas eksperimen I dan siswa untuk kelas eksperimen II terdiri dari 12 siswa.

Hasil evaluasi yang diperoleh pada ketiga pertemuan diakumulasikan terhadap hasil nilai posttest, Berikut gambar grafik nilai evaluasi pada ketiga pertemuan kelas eksperimen I.

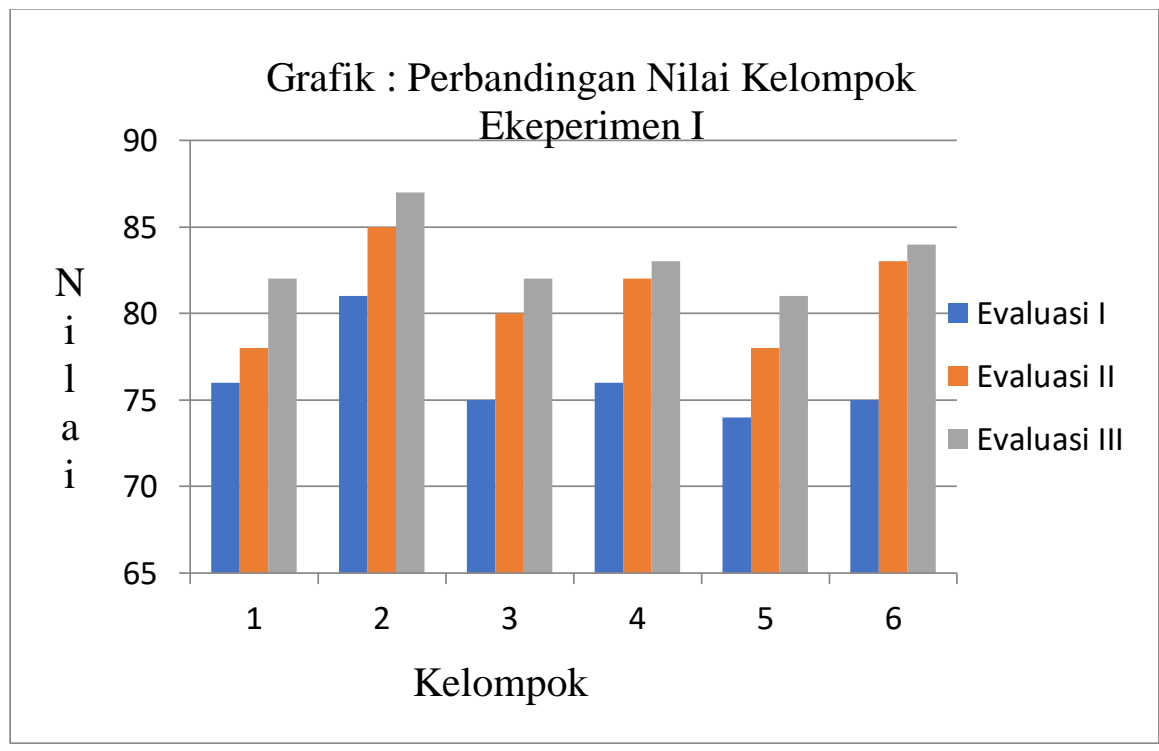

Gambar 2. Perbandingan nilai evaluasi eksperimen I 
Dari data nilai evaluasi pada kelas eksperimen I diatas dapat dilihat kemampuan siswa tiap pertemuan terdapat peningkatan hasil belajar pada pertemuan I,II,dan ke III yang diperoleh dari nilai kelompok. Nilai hasil evaluasi yang diperoleh ada siswa yang mencapai nilai KKM, dan nilai KKM disekolah SMAN 1 Tanjung Tiram adalah 70. Kelompok yang memperoleh nilai terendah untuk evaluasi I yaitu pada kelompok 5 dengan nilai 74, sedangkan kelompok 2 dengan nilai 81, pada evaluasi II terdapat 2 kelompok yang mencapai nilai rendah yaitu pada kelompok 1 dan 5 dengan perolehan nilai 78, sedangkan untuk perolehan nilai tertinggi pada kelompok 2 dengan nilai 85, dan pada evaluasi III, dengan perolehan nilai.

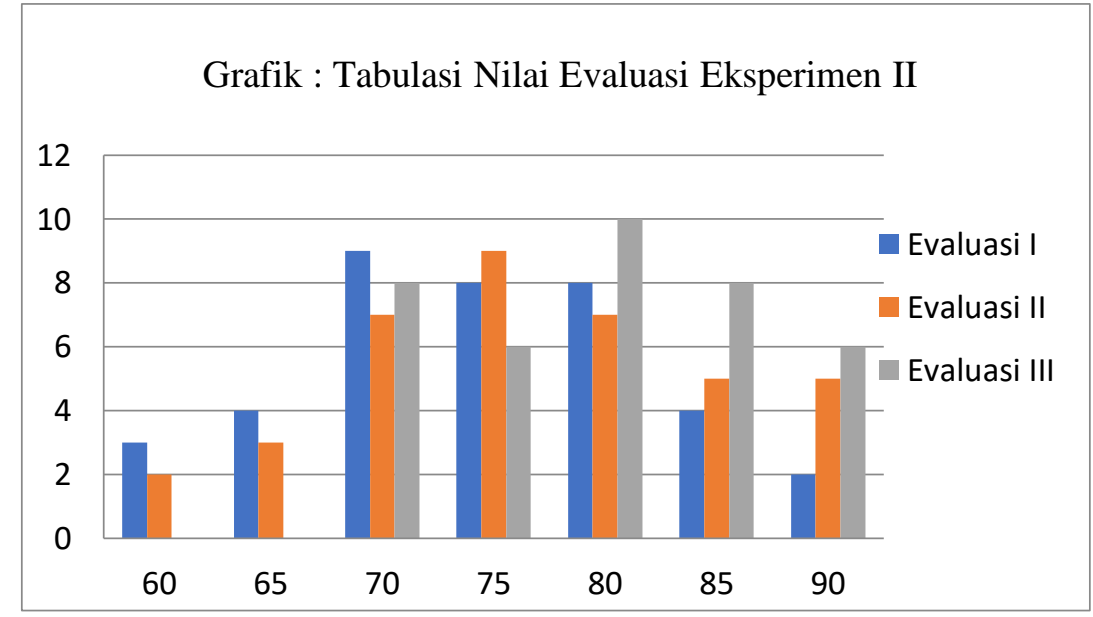

Gambar 3. Perbandingan nilai hasil evaluasi eksperimen II

Dari data nilai hasil evaluasi pada kelas eksperimen II diatas dapat dilihat kemampuan siswa tiap pertemuan terdapat peningkatan hasil belajar dibandingkan pertemuan pertama dan kedua. Nilai hasil evaluasi yang diperoleh ada siswa yang mencapai nilai KKM, dan nilai KKM disekolah SMAN 1 Tanjung Tiram adalah 70. Siswa yang mencapai nilai KKM pada evaluasi I terdiri dari 31 siswa, sedangkan pada evaluasi II terdiri dari 33 siswa dan evaluasi III semua siswa mencapai nilai KKM. Hasil evaluasi diatas menunjukkan bahwa ada perbedaan hasil belajar siswa pada kelas eksperimen I dibandingkan dengan kelas eksperimen II.

Setelah dilakukan proses pembelajaran pada kedua kelas eksperimen diperoleh perbandingan nilai hasil belajar untuk post-test kedua kelas eksperimen seperti pada gambar grafik dibawah ini.

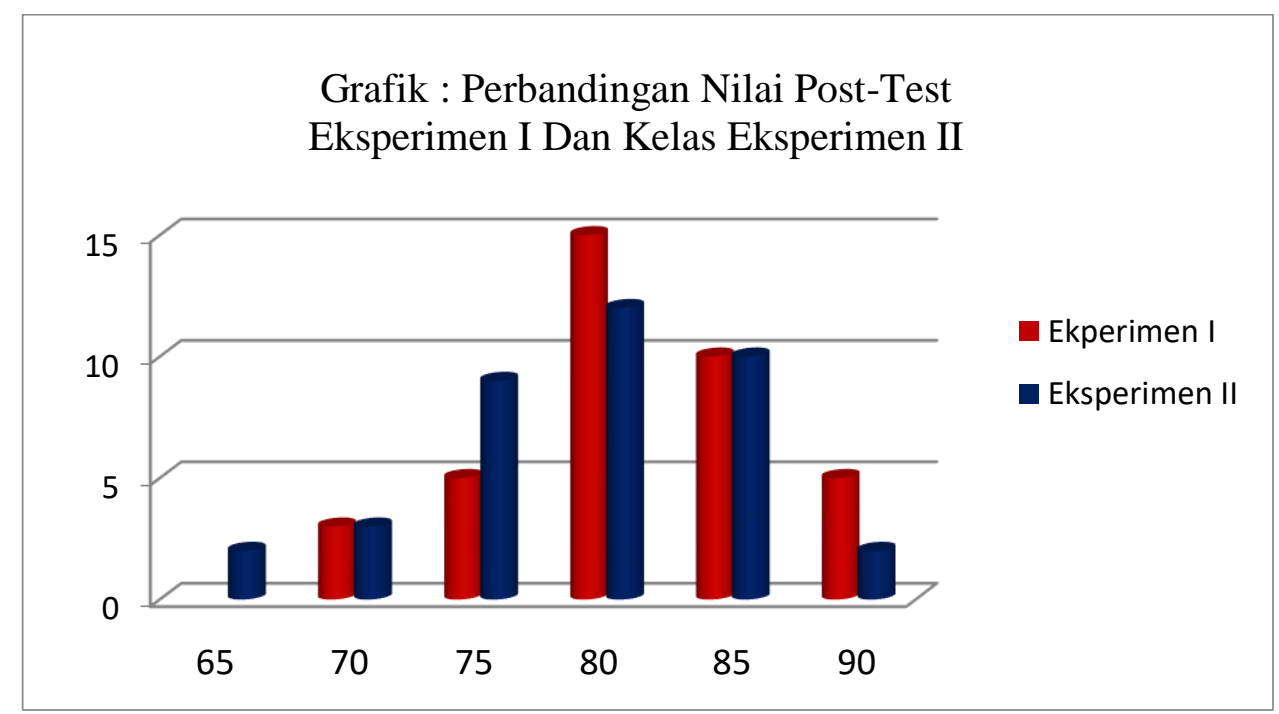

Gambar 4. Perbandingan nilai post-test Eksperimen I dengan Eksperimen II 
Dari data pada gambar grafik 4, tampak adanya perbedaan hasil belajar yang menggunakan model TGT dengan Make A Match. Dengan melihat nilai post-test, yang mencapai KKM pada kelas eksperimen I dan kelas eksperimen II, jelas semua siswa mencapai KKM.

\subsection{Analisis Hasil Penelitian}

\subsubsection{Normalitas Data}

Sebelum dilakukan uji hipotesis terlebih dahulu dilakukan uji prasyarat data yaitu uji normalitas menggunakan uji liliofers yang bertujuan untuk mengetahui apakah penyebaran data pretest dan postest memiliki sebaran data yang berdistribusi normal atau tidak. Sampel berdistribusi normal jika $\mathrm{L}_{\text {hitung }}<$ $\mathrm{L}_{\text {tabel }}$ pada taraf signifikan $\alpha=0,05$.

Tabel 3. Hasil uji normalitas data pretest dan postest

\begin{tabular}{lcccccc}
\hline \multirow{2}{*}{ Kelas } & \multicolumn{3}{c}{ Pretes } & \multicolumn{3}{c}{ Postes } \\
\cline { 2 - 7 } & $\mathbf{L}_{\mathbf{0}}\left(\mathbf{L}_{\text {hitung }}\right)$ & $\mathbf{L}_{\text {tabel }}$ & Keterangan & $\mathbf{L}_{\mathbf{0}}\left(\mathbf{L}_{\text {hitung }}\right)$ & $\mathbf{L}_{\text {tabel }}$ & Keterangan \\
\hline $\begin{array}{l}\text { Eksperimen I } \\
\begin{array}{l}\text { Menggunakan } \\
\text { model TGT }\end{array}\end{array}$ & 0,130 & 0,140 & Normal & 0,126 & 0,140 & Normal \\
\hline $\begin{array}{l}\text { Eksperimen II } \\
\begin{array}{l}\text { Menggunakan } \\
\text { model Make A }\end{array}\end{array}$ & 0,123 & 0,140 & Normal & 0,058 & 0,140 & Normal \\
Match & & & & & & \\
\hline
\end{tabular}

\subsubsection{Homogenitas Data}

Pengujian homogenitas bertujuan mengetahui apakah sampel yang digunakan dalam penelitian berasal dari populasi yang homogen atau tidak, maksudnya apakah sampel yang dipilih dapat mewakili seluruh populasi yang ada. Pengujian homogenitas menggunakan uji kesamaan kedua varians yang memperlihatkan data pretest dan postest berasal dari populasi yang homogen dimana $\mathrm{F}_{\text {hitung }}<\mathrm{F}_{\text {tabel }}$

Tabel 4. data hasil uji homogenitas

\begin{tabular}{cccccc}
\hline Data & $\mathbf{V}_{\text {besar }}$ & $\mathbf{V}_{\text {kecil }}$ & $\mathbf{F}_{\text {hitung }}$ & $\mathbf{F}_{\text {tabel }}$ & Keterangan \\
\hline Pre-test & 57,610 & 55,63 & 1,100 & 1,705 & Homogen \\
\hline Post-test & 44,73 & 30,316 & 1,348 & 1,705 & Homogen \\
\hline
\end{tabular}

\subsubsection{Perhitungan Keberhasilan Belajar (Gain)}

Keberhasilan hasil belajar siswa dengan menggunakan rata-rata gain kelas eksperimen I dan kelas eksperimen II.

Tabel 5. Keberhasilan belajar (Gain)

\begin{tabular}{|c|c|c|c|c|c|}
\hline Kelas & $\begin{array}{c}\text { Nilai } \\
\text { Pre-test }\end{array}$ & $\begin{array}{c}\text { Nilai } \\
\text { Pos-test }\end{array}$ & $\begin{array}{l}\text { Nilai } \\
\text { Gain }\end{array}$ & Kriteria & Keterangan \\
\hline Eksperimen I & 62,625 & 81,25 & 0,54 & \multirow{2}{*}{$\begin{array}{c}\mathrm{G}<0,3=\text { Rendah } \\
0,3<\mathrm{G}>0,7= \\
\text { Sedang } \\
\mathrm{G}>0,7=\text { tinggi }\end{array}$} & Sedang \\
\hline Eksperimen II & 44,5 & 71,37 & 0,52 & & Sedang \\
\hline
\end{tabular}

Berdasarkan tabel diatas dapat dilihat bahwa besar peningkatan hasil belajar pada kelas Eksperimen I lebih tinggi dari pada kelas Eksperimen II. 


\subsubsection{Hipotesis Penelitian}

Hipotesis hasil belajar siswa diuji menggunakan uji t satu pihak, dengan hipotesis sebagai berikut:

- $\mathrm{H}_{0}: \mu_{1} \leq \mu_{2} \rightarrow$ Kelas eksperimen I dan kelas eksperimen II mempunyai kemampuan awal yang sama.

- $\mathrm{H}_{\mathrm{a}}: \mu_{1} \geq \mu_{2} \rightarrow$ Kelas eksperimen I dan kelas eksperimen II mempunyai kemampuan awal yang berbeda.

Tabel 6. Data Pre-Test

\begin{tabular}{ccccc}
\hline No & Kelas & $\begin{array}{c}\text { Rata- rata } \\
\overline{(\boldsymbol{X})}\end{array}$ & $\begin{array}{l}\text { Varians } \\
\left(\left(\boldsymbol{S}^{\mathbf{2}}\right)\right.\end{array}$ & $\begin{array}{l}\text { Jumlah } \\
\text { siswa (n) }\end{array}$ \\
\hline 1 & Eksperimen I & 62,89 & 57,610 & 38 \\
\hline 2 & Eksperimen II & 44,39 & 55,63 & 38 \\
\hline
\end{tabular}

Hipotesis hasil belajar siswa diuji menggunakan uji t satu pihak, dengan hipotesis sebagai berikut:

- $\mathrm{H}_{0}: \mu_{1} \leq \mu_{2} \rightarrow$ Hasil belajar siswa yang dibelajarkan dengan menggunakan TGT dibandingkan dengan siswa yang dibelajarkan menggunakan Make A Match.

- $\mathrm{H}_{\mathrm{a}}: \mu_{1} \geq \mu_{2} \rightarrow$ Hasil belajar siswa yang dibelajarkan dengan menggunakan Make A Match lebih tinggi dibandingkan dengan hasil belajar siswa yang dibelajarkan menggunakan TGT pada materi Larutan Buffer dikelas XI IPA SMAN 1 Tanjung Tiram.

Tabel 7. Data Post-Test

\begin{tabular}{ccccc}
\hline No & Kelas & $\begin{array}{c}\text { Rata- rata } \\
\overline{(\boldsymbol{X})}\end{array}$ & $\begin{array}{l}\text { Varians } \\
\left(\left(\boldsymbol{S}^{\mathbf{2}}\right)\right.\end{array}$ & $\begin{array}{l}\text { Jumlah } \\
\text { siswa (n) }\end{array}$ \\
\hline 1 & Eksperimen I & 81,184 & 30,316 & 38 \\
\hline 2 & Eksperimen II & 73,421 & 44,73 & 38 \\
\hline
\end{tabular}

Dari tabel distribusi hasil belajar pre-test dan post-test kedua sampel merupakan data yang berdistribusi normal dan homogen, selanjutnya dilakukan pengujian hipotesis. Pengujian hipotesis untuk pre-test dan post-test dilakukan dengan uji beda atau uji t. kriteria pengujian hipotesis adalah ,terima $\mathrm{H}_{0}$ jika $\mathrm{t}_{1-1 / 2 \alpha}<\mathrm{t}<\mathrm{t}_{1-1 / 2 \alpha}$ dimana $\mathrm{t}_{1-1 / 2 \alpha}$ didapat dari daftar distribusi $\mathrm{t}$ dengan $\mathrm{d}_{\mathrm{k}}=\left(\mathrm{n}_{1}+\mathrm{n}_{2}-2\right)$ dan $\alpha=0.05$.Hasil pengujian hipotesis dapat dilihat pada tabel berikut:

Tabel 8. Perhitungan Uji-t

\begin{tabular}{|c|c|c|c|c|c|}
\hline No & Data & Rata-rata & $t_{\text {hitung }}$ & $\mathbf{t}_{\text {tabel }}$ & Kesimpulan \\
\hline \multirow{7}{*}{1} & Pre-test kelas & & \multirow{7}{*}{0,39} & \multirow{7}{*}{1,99} & \multirow{7}{*}{$\begin{array}{l}\text { Kemampuan awal } \\
\text { siswa sama yang masih } \\
\text { tergolong rendah }\end{array}$} \\
\hline & Eksperimen I & 6289 & & & \\
\hline & $\begin{array}{c}\text { menggunakan model } \\
\text { TGT }\end{array}$ & & & & \\
\hline & Pre-test kelas & \multirow{4}{*}{44,3} & & & \\
\hline & Eksperimen I & & & & \\
\hline & menggunakan model & & & & \\
\hline & Make A Match & & & & \\
\hline \multirow{6}{*}{2} & Post-test kelas & & \multirow{6}{*}{7,91} & \multirow{6}{*}{1,99} & \multirow{6}{*}{$\begin{array}{l}\text { Ada perbedaan hasil } \\
\text { belajar siswa }\end{array}$} \\
\hline & $\begin{array}{c}\text { Eksperimen II } \\
\text { menggunakan model }\end{array}$ & 81,18 & & & \\
\hline & $T G T$ & & & & \\
\hline & Post-test kelas & \multirow{3}{*}{73,42} & & & \\
\hline & $\begin{array}{c}\text { Eksperimen II } \\
\text { menggunakan model }\end{array}$ & & & & \\
\hline & Make A Match & & & & \\
\hline
\end{tabular}

Dari data diatas diperoleh bahwa untuk nilai pre-test $\mathrm{t}_{\text {hitung }}<\mathrm{t}_{\text {tabel }}$ yaitu $0.39<1,99$ maka $\mathrm{H}_{0}$ diterima sehingga dapat disimpulkan bahwa kemampuan awal siswa pada kelas Eksperimen I sama 
dengan kemampuan awal siswa pada kelas Eksperimen II. Nilai postes $t_{\text {hitung }}>t_{\text {tabel }}$ yaitu 7,91 $>1,99$ maka $\mathrm{H}_{0}$ ditolak dan $\mathrm{H}_{\mathrm{a}}$ diterima sehingga dapat disimpulkan ada perbedaan hasil belajar siswa yang dibelajarkan menggunakan TGT dengan menggunakan Make A Match pada materi Larutan Buffer di SMAN 1 Tanjung Tiram.

\subsection{Pembahasan}

Dari hasil pre-test untuk kedua kelas eksperimen, hanya 20 orang yang mencapai nilai KKM. Pada dua kelas tersebut. Yaitu nilai siswa 70 terdiri dari 10 siswa untuk kelas Eksperimen I dan 10 siswa untuk kelas Eksperimen II. Nilai tertinggi diperoleh oleh 7 siswa untuk kedua kelas eksperimen dengan nilai 75. Setelah dilakukan proses pembelajaran pada kedua kelas diperoleh perbandingan hasil belajar untuk kedua kelas eksperimen seperti pada gambar 4. Dari data pada gambar grafik 2, tampak adanya perbedaan hasil belajar yang menggunakan TGT dengan Model pembelajran Make A Match. Dengan melihat nilai post-test, yang mencapai KKM pada kelas Eksperimen keseluruhan dari siswa pada kelas Eksperimen I yaitu 4 siswa dengan nilai tertinggi 90. Pada kelas Eksperimen II ada 2 siswa yang mencapai KKM dengan nilai tertinggi 90, dan 2 siswa tidak mencapai nilai KKM yaitu rentang nilai dari 65. Melihat data pre-tes dan post-test pada kelas Eksperimen I dan II, ternyata menggunakan model $T G T$ berpengaruh dalam pencapaian hasil belajar siswa yaitu pada kelas eksperimen I dari pada menggunakan model Make A Match yaitu pada kelas ekperimen II. Walaupun di dalam post-test ada beberapa siswa yang mencapai nilai KKM, tetapi hampir seluruh siswa dapat terangkat hasil belajarnya. Nilai terendah pada kelas Eksperimen I pada post-test yaitu 70. Pada kelas Eksperimen II nilai post-test terendah yaitu 65 .

Pembelajaran kooperatif model TGT adalah salah satu tipe atau model pembelajaran yang mudah diterapkan, melibatkan seluruh siswa tanpa harus ada perbedaan status, melibatkan peran siswa sebagai tutor sebaya, dan mengandung unsur permainan. Aktivitas belajar dengan permainan yang dirancang dalam pembelajaran kooperatif model TGT memungkinkan siswa belajar lebih rileks, disamping menumbuhkan tanggungjawab, kerjasama, persaingan sehat, dan keterlibatan belajar (Slavin, 2005). Pembelajaran model TGT adalah salah satu tipe atau model pembelajaran kooperatif yang mudah diterapkan, melibatkan aktivitas seluruh siswa tanpa harus ada perbedaan status, melibatkan peran siswa sebagai tutor sebaya dan mengandung unsur permainan. Dalam TGT siswa dibentuk dalam kelompok-kelompok kecil yang terdiri dari tiga sampai lima siswa yang heterogen, baik dalam prestasi akademik, jenis kelamin, ras, maupun etnis (Aris, 2014). Model pembelajaran Make A Match merupakan mdel pembelajaran yang dikembangkan Lonna Curran. Ciri uatama model ini adalah siswa diminta mencari pasangan kartu yang merupakan jawaban atau pertanyaan materi tertentu dalam pembelajaran. Karakteristik model Make A Match adalah memilih hubungan yang erat dengan karateristik siswa yang gemar bermain (Aris, 2014). Hal - hal yang perlu dipersiapkan jika pembelajaran dikembangkan dengan make a match adalah kartu-kartu. Kartu-kartu tersebut terdiri dari kartu-kartu berisi pertanyaan-pertanyaan dan kartu-kartu lainnya berisi jawaban dari pertanyaanpertanyaan tersebut (Istarani, 2012). Guru menyiapkan kartu yang berisi jawabannya, setiap siswa mencari dan mendapatkan sebuah kartu soal dan berusaha menjawabnya, setiap siswa mencari kartu jawaban yang cocok dengan persoalannya siswa yang benar mendapat nilai-reward, kartu dikumpul lagi dan dikocok, untuk babak berikutnya pembelajaran seperti babak pertama, penyimpulan dan evaluasi, refleksi (Ngalimun,2012).

\section{SIMPULAN DAN SARAN}

\subsection{Simpulan}

Berdasarkan hasil-hasil temuan penelitian, pengujian hipotesis dan pembahasan diperoleh kesimpulan Hasil belajar siswa yang dibelajarkan menggunakan $T G T$ pada materi larutan penyangga dikelas XI IPA SMAN 1 Tanjung Tiram memiliki nilai rata-rata pre-test adalah 62,89 dan nilai ratarata untuk post-test adalah 81,184. Hasil belajar siswa yang dibelajarkan menggunakan Make A Match pada materi larutan penyangga dikelas XI IPA SMAN 1 Tanjung Tiram memiliki nilai rata-rata pre-test adalah 44,3 dan nilai rata-rata untuk post-test adalah 73,421. Hasil hipotesis dalam penelitian ini yaitu dan Ha diterima dengan nilai $t_{\text {hitung }}>t_{\text {tabel }}$ yaitu 7,91 > 1,99 Maka dari hasil analisa terhadap rumusan hipotesis menunjukkan bahwa ada perbedaan hasil belajar siswa yang dibelajarkan menggunakan video demonstrasi pada materi larutan buffer dikelas XI IPA SMAN 1 Tanjung Tiram. 


\subsection{Saran}

Berdasarkan kesimpulan yang telah diperoleh dari hasil penelitian ini maka dapat disarankan beberapa hal yaitu sebagai berikut:

1. Penelitian yang menggunakan model TGT dengan model Make A Match dengan media video demonstrasi masih perlu dilakukan evaluasi terstruktur untuk setiap siswa.

2. Bagi peneliti dan calon guru sebagai bahan persiapan diri menjadi guru dan menambah wawasan peneliti tentang proses belajar mengajar dengan menggunakan model TGT dan Make A Match.

\section{DAFTAR PUSTAKA}

Ismayanti , A. (2010). Penerapan Media Komputer (Animasi Flash Power Point) Untuk Meningkatkan Hasil Belajar Kimia Siswa Kelas XI. Jurnal Pendidikan Kimia : Bengkulu.

Istarani, (2012). 58 Model Pembelajaran Inovatif. Medan : Media Persada.

Kartika, A.(2015). Pengaruh Model Pembelajaran Kooperatif Tipe TGT (Teams games Tournament) Terhadap Aktivitas dan Peningkatan Hasil Belajar Siswa pada Pembelajaran Hidrolisis garam yang Menggunakan Media Kartu Kuartet. Skripsi. IKA IKIP.Malang.

Markono. (2011). Perbedaan Model Pembelajaran Kooperatif Tipe Teams Games Tournament dan Model Pembelajaran Konvensional Pada Hasil Belajar Ekonomi Mahasiswa FE UNPAB. Jurnal Ilmiah Abdi Ilmu. (Volume 4 Nomor 2) : 613.

Muslim, B. (2015). Pembelajaran Hidrolisis Garam Menggunakan Model Pembelajaran Pemecahan Masalah Tipe Galet. Jurnal Keguruan. (Volume 1 Nomor 1): 76.

Ngalimun. (2012). Strategi dan Model Pembelajaran. Banjarmasin : Aswaja Pressindo.

Slavin, R. (2005). Cooperatif Learning : Teori, Riset, dan Praktik. Bandung : Nusa Media.

Suyono, dkk. (2009). Pengembangan Model Pembelajaran Kimia Berorientasi Keterampilan Generik Sains pada Siswa SMA di Propinsi Lampung. Jurnal Keguruan. (Volume 1 Nomor 1) : 01. 